\title{
Financial Innovation and Aggregate Risk Sharing
}

\author{
Rodrigo J. Hernandez1, Pu Liu²*, Yingying Shao³ \\ ${ }^{1}$ Radford University, Radford, USA \\ ${ }^{2}$ Department of Finance, Sam M. Walton College of Business, University of Arkansas, Fayetteville, USA \\ ${ }^{3}$ Department of Finance, College of Business and Economics, Towson University, Towson, USA \\ Email: rjhernand@radford.edu, *pliu@walton.uark.edu, yshao@towson.edu
}

How to cite this paper: Hernandez, R.J., Liu, P. and Shao, Y.Y. (2018) Financial Innovation and Aggregate Risk Sharing. Theoretical Economics Letters, 8, 2182-2198. https://doi.org/10.4236/tel.2018.811143

Received: June 19, 2018

Accepted: August 4, 2018

Published: August 7, 2018

Copyright (C) 2018 by authors and Scientific Research Publishing Inc. This work is licensed under the Creative Commons Attribution International License (CC BY 4.0).

http://creativecommons.org/licenses/by/4.0/

\begin{abstract}
In this paper we examine the impact of financial innovations on real economy. Based on data for US banks' off-balance sheet activities from 1995 to 2013, we investigate aggregate risk sharing in two different channels: Personal consumption smoothening and personal income insurance. The results show that the use of financial innovations contributes to a reduction in the exposure of personal income and consumption to state-specific economic shocks, and the results suggest a positive role played by financial innovations in real economy.
\end{abstract}

\section{Keywords}

Financial Innovation, Consumption Smoothing, Income Insurance

\section{Introduction}

The existing literature on innovation largely focuses on innovating activities in the industrial context and examines the associated wealth effect. For example, using a sample of Dutch manufacturing firms, Marsili and Salter [1] report that the homogeneity of return performance tends to be higher in high-technology sectors than low-technology sectors. Ebersberger et al. [2] document similar findings using the data from Finland, Netherlands and the UK.

There is anecdotal evidence that financial innovations adopted by the US financial sector in the past few centuries, just like the innovations in other sectors, have a persistent and significant impact on the US economy. However, largely due to the scarcity of patent applications filed by the financial service industry and the paucity of empirical data on financial innovating activities, few studies have investigated the real effect of financial innovation [3] [4]. 
Most of studies in the extant literature examine the effect of specific forms of innovations on the economy, such as the introduction of new financial products to the market [5], development of new analytical techniques [6], or adoption of new business models [7] [8]. For example, studies have suggested that loan sales and securitizations, by converting illiquid loans into tradable assets and hence conserving valuable capital, enhance banks' liquidity and credit risk management and allow banks to engage in aggressive risk-taking lending [9] [10] [11], leading to an increase in credit supply [11] [12] [13] [14].

In this study, we examine the impact of financial innovations in a general term on the real economy. The literature assessing the effect of financial innovations in the real sector tends to focus on economic growth such as GDP growth or industrial growth [15] [16] [17] [18], while little attention has been paid to individual consumers. We attempt to fill in this gap in the study. If financial innovations reshape banks' risk-taking behavior and affect banks' credit supply as suggested in previous studies, then we expect to observe the impact of innovations on personal consumptions and income.

In this study, we follow the risk sharing literature [19] to empirically examine how financial innovations affect personal income and consumption patterns caused by economic output shocks. Using US banks' regulatory filings (Call Reports), we use the off-balance-sheet data for all the banks headquartered in a state as representative of financial innovations for that state in each year between 1995 and 2013 to study how financial innovations reduce the exposure of personal income and consumption to state-specific economic shocks.

We posit that financial innovations contribute to the aggregate consumption risk sharing via enhanced a credit supply. As suggested by early studies, an intensification of financial innovation over time allows banks to actively engage in more risk-taking lending and issue more loans. The increase in credit supply facilitates consumers' access to credit, which benefits consumers from reducing their needs to constrain personal consumption when facing economic shocks. We therefore would expect to observe in the real economy a smoothened consumption, for which the literature has defined as a consumption risk sharing by sheltering consumption from economic shocks. The results in our study provide supportive evidence on this hypothesis.

We next focus on personal income which is also closely tied to local economic condition. In the risk sharing literature, aggregate income insurance refers to the protection that personal income can be sheltered from state-specific output shocks. In seeking the relationship between aggregate personal income insurance and the development of financial innovation, we again rely on a credit channel whereby financial innovation increases credit supply to entities including local businesses. In a given state, local residents' personal income is largely supported by the businesses in the area, especially small businesses, which often rely on personal contributions from owners and employees to satisfy financing needs, especially when facing local macroeconomic shocks. The positive effect of finan- 
cial innovation on credit supply provides external financing source to local businesses hence reduces the reliance on personal contributions from business owners and employees, which ultimately could stabilize the income of owners and employees and making their personal income less sensitive to local macroeconomic shock. This tie between personal wealth and the financing of local businesses leads us to hypothesize that personal income insurance may improve with use of financial innovation, as the latter provides external financing of local businesses, which ultimately benefits the business owners and employees' wealth. Our empirical analysis supports this hypothesis.

Our paper stands in the growing research on financial innovation. Previous studies tend to focus on the effect of financial innovation on the banking industry such as the effect on banks' performance and safety. Few papers have empirically estimated the effect of financial innovation on the real sector. We explore this possibility here. By focusing on the aggregate effect of financial innovation on personal consumption and income, our paper complements previous findings in the real sector that mainly focuses on economic and industrial growth effect.

By documenting an intensification of innovation in the banking industry contributes to aggregate risk sharing through two perspectives, the consumption smoothing and personal income insurance, our findings extend the relative scarce literature on aggregate risk sharing, which tends to focus on individual wealth effect.

The rest of the paper is organized as follows. In Section 2 we review the literature and present the models used to test for risk sharing. In Section 3 we describe the empirical methodology, data and sample construction. In Section 4 we present the results and in Section 5 we conclude the paper.

\section{Literature Reviews and Models}

\subsection{Financial Innovation and Risk Sharing}

How financial innovation affects economy and the banking industry is still a debate in the literature. One strand of research argues that financial innovation could be harmful to bank safety because innovation may encourage aggressive risk taking. The accelerated credit supply could induce over valuation in asset prices which will eventually lead to price decline, as evidenced in the 2007-2009 financial crisis. Several studies examining the 2007-2009 financial crisis attribute the crisis to the agency problems introduced by financial innovation related to asset securitization [20]. Taking the example of loan sales and securitizations, which is a major category of off-balance-sheet activities, studies have shown that banks lose incentives to actively monitor and manage the credit risk on the loans after the loans are sold or securitized as a result of credit risk transfer. Piskorski et al. [21] argue that this lack of incentive to monitor was one of the reasons which leads to higher default rate in securitized loans than un-securitized loans.

There are studies, on the contrary, document a positive relation between fi- 
nancial innovation and bank performance such as bank growth, efficiency, and credit supply [22]. Merton [23] argues that financial innovation encourages banks to improve the quality and services and claims that "Financial innovation is viewed as the 'engine' driving the financial system towards its goal of improving the performance of the 'real economy"'. A recent study of Houston et al. [24] provides evidence that financial innovation leads to improved information sharing, which ultimately improves banking efficiency. Liu and Shao [25] find that small business loans securitizations contribute to the smoothening of state personal income volatility.

Our study is based on the study of Allen and Gale (1994) that suggests a risk sharing benefits of financial innovation. The literature has documented that financial innovation, when used as risk management tools, banks can transfer some, if not entire, state-specific output risks to the financial institutions in other states. For example, loan sales reduce repayment risks caused by the economic downturn of one specific state, and thus reduce local banks' credit risk, if not alleviate completely. In addition, the use of interest rate derivatives allows banks to effectively manage their interest rate risk embedded in taking deposits and issuing loans. By better managing interest rate risk, liquidity risk and credit risks, banks are able to free up capital reserves and to engage in more risk-taking lending, leading to a positive impact on credit supply [11] [12] [13] [14].

We follow this line of risk sharing literature and empirically examine the contribution of financial innovation to aggregate risk sharing in the real economy via an enhanced credit supply channel. We specifically pay attention to the effect to personal income and consumption pattern in response to economic output shocks. Below we describe the theoretical framework that we follow Asdrubali et al. [19] in examining aggregate risk sharing of personal income and consumption.

\subsection{Testing Consumption Smoothing}

Commercial banks largely take deposits from and make loans to local clients. As a result, banks' sources of funds and the risks of loan repayments are severely exposed to local or state-specific economic shocks. When banks are able to utilize innovative financial tools and instruments, they may manage financial risks such as interest rate risk, liquidity risk and credit risk in a more efficient and effective manner, consequently generating a positive effect to the availability of credit, variety and range of services. The increase in credit supply will benefit consumers as many studies have found that aggregate consumption is positively correlated with the availability of household debts. For instance, McCarthy [26] reports a significant link between availability of credit and durable goods expenditures. Bacchetta and Gerlach [27] document that growth in mortgage and consumer credit is positively correlated with the growth in non-durable goods and services expenditures.

According to the aggregate risk sharing literature, aggregate consumption risk 
sharing is achieved when consumers' spending is not sensitive to economic output shocks. The studies in this literature has documented that increased borrowing and lending in credit markets contribute to the smoothening of personal consumptions such that consumers will not need to halt their consumption when facing macroeconomic risk [19].

Based on the above discussions that financial innovation facilitates banks' active management of interest rate risk, liquidity and credit risk, which can free up bank's required capital and allow banks to make more loans and/or issue loans at a lower cost, we conjecture that the increase in consumers' access to credit could consequently alleviate the adverse impact of economic shocks on personal consumptions, leading to a smoothened consumption pattern.

To test the impact of financial innovation on aggregate consumption risk sharing, we follow a methodology developed by Asdrubali et al. [19] and later was extensively used in the literature. The consumption risk sharing across states is measured through a panel regression model in the following form:

$$
\Delta \ln \mathrm{CON}_{t}^{k}=\gamma \Delta \ln \mathrm{GSP}_{t}^{k}+\varepsilon_{t}^{k},
$$

where $\Delta \ln \operatorname{CON}_{t}^{k}$ denotes the state-specific growth rate of private consumption for state $k$ in year $t$, and $\Delta \operatorname{lnGSP}_{t}^{k}$ is the state-specific growth rate of gross state product for state $k$ in year $t$, and all variables are measured in per capita terms, deflated to 1970 value. The growth rates of the state-specific variables are constructed using state-level variables minus the mean across states minus the mean across time.

Based on Asdrubali et al. [19], if consumption smoothing is fully achieved, personal consumption will not be affected by state-level economic output shocks, hence the relationship between consumption and output should be identical across states. Thus we would expect to see a value of zero for regression coefficient $\gamma$, indicating perfect insurance through consumption smoothing. On the contrary, a value of one for the regression coefficient $\gamma$ indicates a one-to-one co-movement between consumption and output, implying zero insurance through consumption smoothing.

\subsection{Testing Income Insurance}

The above discussion has established the relation between personal consumptions moothing and financial innovation. This thread of interconnection motives our next hypothesis that banks' financial innovation can benefit social wealth by helping reduce the volatility of personal income of the owners and employees of local businesses, i.e., a personal income insurance effect. We follow the literature and use the following regression model to measure the degree of income insurance [19] [28]:

$$
\Delta \ln \mathrm{GSP}_{t}^{k}-\Delta \ln \mathrm{SPI}_{t}^{k}=\beta \Delta \ln \mathrm{GSP}_{t}^{k}+\varepsilon_{t}^{k},
$$

where $\Delta \ln \mathrm{GSP}_{t}^{k}$ is the state-specific growth rates of gross state product for state $k$ in year $t$, and $\Delta \ln \mathrm{SPI}_{t}^{k}$ denotes the state-specific growth rates of state 
personal income for state $k$ in year $t$. All of the variables are measured in per capita terms and deflated to 1970 value. The state-specific variables are constructed using state-level variable minus the mean across states minus the mean across time.

Based on Equation (2), if full income smoothing is achieved, all states should have identical growth rates of income because the income does not co-move with output, while zero income insurance implies a one-to-one relationship between income and output. Because the regression coefficient $\beta$ in Equation (2) measures the degree of income insurance, hence we expect to see a range of value between zero and one, with zero implying no income insurance, and a value of one indicating perfect income insurance.

\section{Empirical Methodology and Sample Construction}

\subsection{Empirical Methods}

The first objective of this study is to examine whether financial innovation contributes to a reduction in consumption's exposure to idiosyncratic output risk. We thus include an additional variable OBS in Equation (1), which measures the overall off-balance-sheet activities of all banks in a given state. We use this variable as a proxy of the overall usage of financial innovations in a state, and we also allow this variable to vary by state and over time in the following regression equation:

$$
\begin{aligned}
\Delta \ln \mathrm{CON}_{t}^{k} & =\alpha+\gamma_{0} \Delta \ln \mathrm{GSP}_{t}^{k}+\gamma_{1} \mathrm{OBS}_{t}^{k} \times \Delta \ln \mathrm{GSP}_{t}^{k}, \\
& +\gamma_{2} \mathrm{OBS}_{t}^{k}+\delta^{k}+\tau_{t}+\varepsilon_{t}^{k}
\end{aligned},
$$

where $\mathrm{OBS}_{t}^{k}$ measures the off-balance-sheet activities in state $k$ in year $t$. It is defined in two ways: First, it is computed as the ratio of the total value of off-balance-sheet items to the total assets of all banks in a given state; second, it is measured as the growth rate of total value of off-balance-sheet items of all banks. $\delta^{k}$ and $\tau_{t}$ are dummy variables measuring state and time fixed effects to control for omitted variables respectively.

In this regression, the key variable of interest is $\mathrm{OBS}_{t}^{k} \times \Delta \ln \mathrm{GSP}_{t}^{k}$, the interaction term between output growth and financial innovation. The regression coefficient $\gamma_{0}$ measures the average degree of uninsured idiosyncratic output risk without financial innovation, and the regression coefficient $\gamma_{1}$ of the interaction term describes the uninsured idiosyncratic output risk under the influence of financial innovation. If increased financial innovation contributes to consumption risk sharing, we expect a negative sign for $\gamma_{1}$.

In order to examine whether income insurance changes with the development of financial innovation, we augment Equation (2) by including the variable OBS as the measurement forfinancial innovation:

$$
\begin{aligned}
\Delta \ln \mathrm{GSP}_{t}^{k}-\Delta \ln \mathrm{SP}_{t}^{k} & =\alpha+\beta_{0} \Delta \ln \mathrm{GSP}_{t}^{k}+\beta_{1} \mathrm{OBS}_{t}^{k} \times \Delta \ln \mathrm{GSP}_{t}^{k} \\
& +\beta_{2} \mathrm{OBS}_{t}^{k}+\delta^{k}+\tau_{t}+\varepsilon_{t}^{k}
\end{aligned}
$$


where $\mathrm{OBS}_{t}^{k}$, defined as before, measures the degree of financial innovation of state $k$ in year $t . \delta^{k}$ and $\tau_{t}$ are dummy variables measuring state and time fixed effects respectively.

Again, in this regression, the key variable of interest is $\mathrm{OBS}_{t}^{k} \times \Delta \ln \mathrm{GSP}_{t}^{k}$, the interaction term between output growth and financial innovation. The regression coefficient $\beta_{1}$ measures the increase in income insurance associated with one-unit increase in financial innovation. The regression coefficient $\beta_{0}$ measures the average degree of income insurance without financial innovation, and $\beta_{0}+\beta_{1}$ measures the total effect of income insurance related to financial innovation.

\subsection{Data}

In our empirical examinations, we use the panel data for the 50 US states and Washington D.C. over the period from 1995 to 2013. The data in this study are obtained from two main sources: (1) Call Report data are obtained from the Federal Reserve Bank that contains quarterly accounting information for all the insured commercial banks in the USA, and (2) historical state-level macroeconomic data are obtained from Bureau of Economic Analysis (BEA).

In measuring the degree of financial innovation at the aggregate level in each state, we use the data in Schedule RC-L of Call Report in December of each year ${ }^{1}$. Due to the changes in reporting requirements over time, some of the call report items are not comparable across time in measuring the overall off-balance-sheet activities of banks. We form consistent time-series by analyzing the call report forms over time. Appendix describes the call report data items that are used to form the consistent time series of off-balance-sheet activities.

We measure the off-balance-sheet (OBS) activities of banks for a given state in two ways: first, we define OBS as the ratio of total value of off-balance-sheet items and total assets of all banks for that state; second, we compute OBS as the growth rate of total value of off-balance-sheet items of all banks.

The state-level macroeconomic data, such as Gross State Product (GSP), personal income (SPI), and state retail sales data are obtained from Bureau of Economic Analysis (BEA). For a given state, we divide these indicators by population and deflate by the consumer price index to year 1970 to obtain state-level real per capita variables.

Since private consumption (CON) data at the state level are not directly available, we estimate state-level personal consumption by using the state retail sales data rescaled by the ratio of total (US-wide) private consumption to total US retail sales. Table 1 lists the state-level mean value of the growth rates in personal consumption, output, and income, respectively. Consistent with the common findings in the macroeconomics literature, there is a distinctive heterogeneity across states in these indicators. On a national basis, the statistics in ${ }^{1}$ The data are available at Federal Reserve Bank of Chicago's website: https://www.chicagofed.org/banking/financial-institution-reports/commercial-bank-data. 
R. J. Hernandez et al.

Table 1. Summary statistics on economic indicators.

\begin{tabular}{|c|c|c|c|}
\hline State & Consumption & GSP & Personal Income \\
\hline Alabama & 1.27 & 0.92 & 1.00 \\
\hline Alaska & 0.51 & 1.49 & 1.36 \\
\hline Arizona & 1.10 & 0.52 & 0.89 \\
\hline Arkansas & 1.07 & 0.96 & 1.36 \\
\hline California & 1.39 & 1.60 & 1.46 \\
\hline Colorado & 0.35 & 1.14 & 1.29 \\
\hline Connecticut & 1.54 & 1.20 & 1.61 \\
\hline Delaware & 0.94 & 0.88 & 0.82 \\
\hline District of Columbia & -1.06 & 1.74 & 1.65 \\
\hline Florida & 0.89 & 0.64 & 0.78 \\
\hline Georgia & 0.59 & 0.54 & 0.65 \\
\hline Hawaii & 0.38 & 0.39 & 0.62 \\
\hline Idaho & 1.53 & 0.43 & 0.93 \\
\hline Illinois & 1.10 & 1.08 & 1.06 \\
\hline Indiana & 1.17 & 1.07 & 0.87 \\
\hline Iowa & 1.63 & 1.63 & 1.52 \\
\hline Kansas & 1.40 & 1.35 & 1.60 \\
\hline Kentucky & 0.64 & 0.76 & 1.08 \\
\hline Louisiana & 2.34 & 1.55 & 1.67 \\
\hline Maine & 1.38 & 0.97 & 1.27 \\
\hline Maryland & 1.01 & 1.69 & 1.34 \\
\hline Massachusetts & 0.72 & 1.71 & 1.67 \\
\hline Michigan & 1.03 & 0.30 & 0.56 \\
\hline Minnesota & 1.24 & 1.34 & 1.42 \\
\hline Mississippi & 1.67 & 0.75 & 1.29 \\
\hline Missouri & 0.91 & 0.92 & 0.94 \\
\hline Montana & 1.44 & 1.68 & 1.73 \\
\hline Nebraska & 1.97 & 1.68 & 1.61 \\
\hline Nevada & 0.42 & -0.12 & 0.12 \\
\hline New Hampshire & 2.58 & 1.37 & 1.65 \\
\hline New Jersey & 1.76 & 1.03 & 1.24 \\
\hline New Mexico & 0.71 & 0.62 & 1.08 \\
\hline New York & 2.24 & 1.91 & 1.49 \\
\hline North Carolina & 0.13 & 0.84 & 0.78 \\
\hline North Dakota & 3.44 & 4.12 & 3.18 \\
\hline Ohio & 1.12 & 1.11 & 0.94 \\
\hline Oklahoma & 1.37 & 2.08 & 2.04 \\
\hline Oregon & 0.41 & 1.48 & 0.88 \\
\hline Pennsylvania & 0.99 & 1.60 & 1.40 \\
\hline Rhode Island & 1.39 & 1.47 & 1.44 \\
\hline
\end{tabular}




\section{Continued}

\begin{tabular}{clll}
\hline South Carolina & 1.05 & 0.50 & 0.97 \\
South Dakota & 2.51 & 1.85 & 1.87 \\
Tennessee & 0.84 & 0.70 & 1.03 \\
Texas & 1.37 & 1.95 & 1.67 \\
Utah & 1.83 & 1.59 & 1.34 \\
Vermont & 2.11 & 1.16 & 1.79 \\
Virginia & 1.04 & 1.36 & 1.32 \\
Washington & 2.09 & 1.49 & 1.39 \\
West Virginia & 2.05 & 1.42 & 1.27 \\
Wisconsin & 1.18 & 1.15 & 1.14 \\
Wyoming & 2.60 & 2.25 & 2.52 \\
Mean Value (\%) & 1.28 & 1.25 & 1.31 \\
Standard Deviation (\%) & 0.75 & 0.65 & 0.50 \\
\hline
\end{tabular}

This table provides the average growth rate (in \%) in economic indicators including consumption, gross state production (GSP), and personal income for 50 States and Washington DC. in the US. A between 1995 to 2013. The growth rates are computed based on per capita data of annual state-level macroeconomic measurements obtained from Bureau of Economic Analysis (BEA), and deflated to 1970.

the bottom two rows show that personal consumption growth is accompanied with the highest degree of volatility $(0.75 \%)$ while personal income has a relatively high growth rate $(1.31 \%)$ yet relatively low volatility $(0.50 \%)$.

Figure 1 displays the average growth rates of state output (GSP), consumption spending (CON), and personal income (SPI) across states for each year from 1995 to 2013. The figure reveals a lead-lag relation between the growth rate in GSP and the growth rates in personal income and consumption. Whenever GSP growth rate showed a big dip, for example in years 2000, 2002 and 2007 respectively, we observe a lagged reduction in the growth rates of personal income and consumption, reflecting the fact that personal income and consumption are largely affected by the macroeconomic conditions. Figure 2 geographically displays the average use of financial innovation by states in a heat map view. It is revealed that the regions along the East and West coasts tend to have a larger use of financial innovation, comparing to the states in other regions.

\section{Results}

We first estimate regression Equation (3) to examine whether financial innovations contribute to consumption risk sharing, and report the results in Table 2 .

As discussed in Section 3, the key variable of interest in this regression is the interaction term between financial innovation (measured as $O B S$ ) and state output growth, and a negative sign for regression coefficient $\left(\gamma_{1}\right)$ indicates that increased financial innovation contributes to consumption risk sharing. From the results in Column (1) of Table 2, we observe that the average impact of idiosyncratic output risk on consumption, as measured by $\gamma_{0}$, is about $42 \%$ 


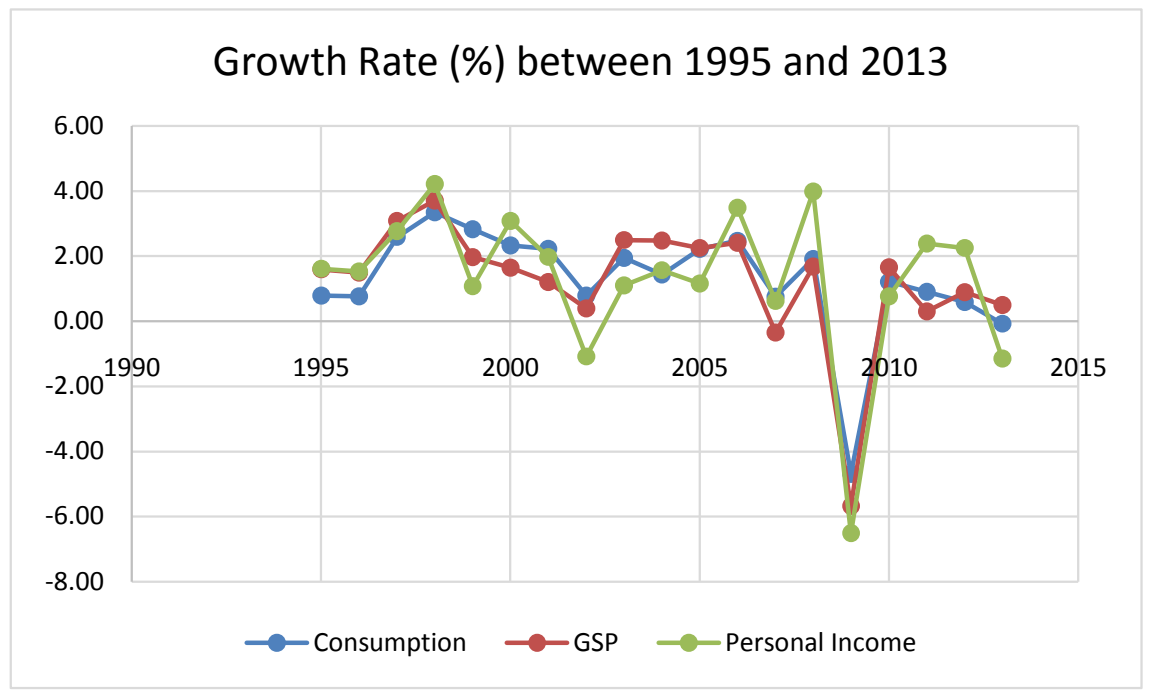

Figure 1. Average growth rates between 1995 and 2013. This figure depicts the national average growth rate (including 50 States and Washington DC in the USA) (in \%) in economic indicators including consumption, gross state production, and personal income between 1995 to 2013. The growth rates are computed based on per capita data of annual state-level macroeconomic measurements obtained from Bureau of Economic Analysis (BEA), and deflated to 1970.

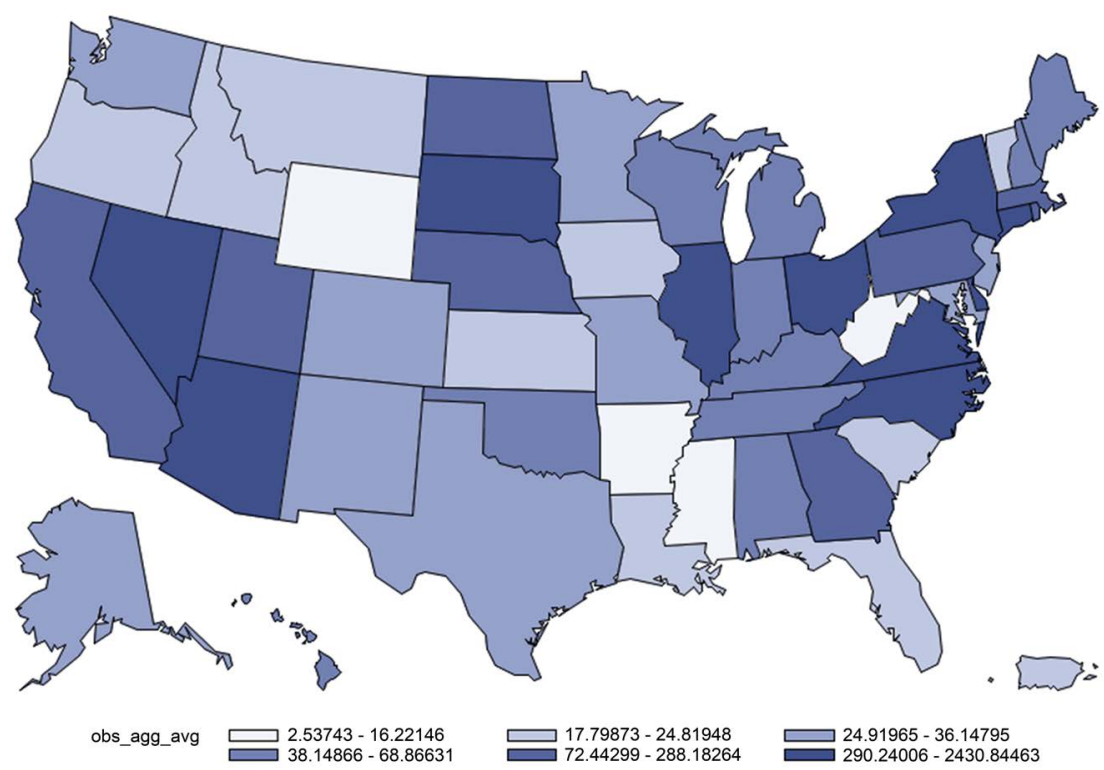

Figure 2. Geographical presentation of use of financial innovations. This figure depicts the average use of financial innovations across 50 States and Washington DC in the US. A between 1995 to 2013 . The degree of financial innovation of a state is defined as the ratio (in \%) of the aggregate outstanding off-balance-sheet items to the total assets of all banks in that state as reported in Schedule RC-L of Call Report in December each year. Call Report data are obtained from the Federal Reserve Bank of Chicago.

without the securitization of mortgage loans. This estimate is both economically and statistically significant. The regression coefficient for the interaction term, $\gamma_{1}(=-0.8 \%)$ has the expected negative sign and is statistically significant. 
Table 2. Financial innovation and consumption smoothing.

\begin{tabular}{|c|c|c|c|}
\hline Variables & Expected Sign & Model & Model \\
\hline & Sign & (1) & (2) \\
\hline \multirow{2}{*}{$\Delta \ln \mathrm{GSP}_{t}^{k}\left(\gamma_{0}\right)$} & + & $0.420^{\star * *}$ & $0.445^{\star * *}$ \\
\hline & & $(0.0344)$ & $(0.0341)$ \\
\hline \multirow[t]{2}{*}{$\mathrm{OBS}_{t}^{k} \times \Delta \ln \mathrm{GSP}_{t}^{k}\left(\gamma_{1}\right)$} & - & $-0.0814^{\star *}$ & $-0.109^{\star}$ \\
\hline & & $(0.0373)$ & $(0.0602)$ \\
\hline \multirow[t]{2}{*}{$\mathrm{OBS}_{t}^{k}$} & - & -0.00983 & 0.00197 \\
\hline & & $(0.0139)$ & $(0.00221)$ \\
\hline \multirow[t]{2}{*}{ Constant } & & $0.00771^{* * *}$ & $0.00783^{* * *}$ \\
\hline & & $(0.00120)$ & $(0.00119)$ \\
\hline State Dummies & & Yes & Yes \\
\hline Year Dummies & & Yes & Yes \\
\hline $\mathrm{N}$ & & 969 & 918 \\
\hline $\mathrm{R}^{2}$ & & 0.166 & 0.165 \\
\hline
\end{tabular}

This table presents the results of regression (3):

$\Delta \ln \mathrm{CON}_{t}^{k}=\alpha+\gamma_{0} \Delta \ln \mathrm{GSP}_{t}^{k}+\gamma_{1} \mathrm{OBS}_{t}^{k} \times \Delta \ln \mathrm{GSP}_{t}^{k}+\gamma_{2} \mathrm{OBS}_{t}^{k}+\delta^{k}+\tau_{t}+\varepsilon_{t}^{k}$, where $\Delta \ln \mathrm{CON}_{t}^{k}$ denotes the state-specific growth rates of private consumption for state $\mathrm{k}$ in year $\mathrm{t}$ and $\Delta \ln \mathrm{GSP}_{t}^{k}$ is the state-specific growth rates of gross state product for state $k$ in year $t . \Delta \ln \mathrm{CON}_{t}^{k}$ and $\Delta \ln _{\mathrm{GSP}_{t}^{k}}$ are measured in per capita terms. The growth rates of real per capita variables are calculated as the first differences of the natural $\log$ of per capita-level values deflated to $1970 . \mathrm{OBS}_{t}^{k}$ measures the degree of financial innovation of state $k$ in year $t$ and is defined as: 1) the ratio of the aggregate outstanding off-balance-sheet items to the total assets of all banks in a state as reported in Column (1);2) the growth rate of aggregate outstanding off-balance-sheet items of all banks in that state, as reported in Column (2). The OBS data are collected from Schedule RC-L of Call Report in December in each year from the Federal Reserve Bank of Chicago. See Appendix for the details in constructing a consistent time series of this variable. $\delta^{k}$ and $\tau_{t}$ are dummy variables measuring state and time fixed effects respectively. Standard errors are reported in parenthesis. ${ }^{*}$ significant at $10 \%$; ${ }^{*}$ significant at $5 \%$; ${ }^{* *}$ significant at $1 \%$.

Consistent with our expectation, the results show that with the increase in the use of financial innovation, the degree of the shock to the consumption due to idiosyncratic output risk reduces to $34 \%(42 \%-8 \%)$, a significant improvement in smoothening the consumption.

We next repeat regression Equation (3) by replacing the level of the OBS variable (as measured by the ratio of total OBS to total assets) by the growth rate in OBS to examining the effect related to the growth in financial innovation, as banks have significantly engaged in more off-balance-sheet activities overtime. The results in Column (2) of Table 2 show similar effect of the growth of financial innovation on consumption risk sharing. The regression coefficient is negative and statistically significant, suggesting that the growth in financial innovations also enhance consumption risk sharing, reflecting a positive role played by the development of financial innovations.

The findings in Table 2 are consistent with the hypothesis that innovative banking activities provide protections to consumers by sheltering their con- 
sumptions from economic shocks. The results in Table 2, however, also highlight the potential dark side of financial innovations. While consumers may benefit from the consumption insurance due to banking sector's financial innovations, the insurance may also shield consumptions from reductions caused by economic shocks and thus protect the overvaluation in asset price momentarily until economic shocks eventually lead to the decline in asset prices, a phenomenon we observe during the 2007-2009 financial crisis.

Having provided the evidence that financial innovations contribute to personal consumption smoothening and reduce the sensitivity of individual's consumption to state output shocks, we then switch our test to examine if financial innovations have an effect to personal income by reducing personal income's exposure to output shocks. In Table 3 we present the results of regression Equation (4) which examines whether financial innovations enhance personal income insurance.

Table 3. Financial innovation and income insurance.

\begin{tabular}{|c|c|c|c|}
\hline Variables & Expected Sign & Model & Model \\
\hline & Sign & (1) & (2) \\
\hline \multirow[t]{2}{*}{$\Delta \ln \operatorname{GSP}_{t}^{k}\left(\beta_{0}\right)$} & + & $0.392^{\star * *}$ & $0.381^{\star * *}$ \\
\hline & & $(0.0217)$ & $(0.0213)$ \\
\hline \multirow[t]{2}{*}{$\mathrm{OBS}_{t}^{k} \times \Delta \ln \mathrm{GSP}_{t}^{k}\left(\beta_{1}\right)$} & + & $0.0732^{\star * *}$ & $0.129^{*}$ \\
\hline & & $(0.0136)$ & $(0.0697)$ \\
\hline \multirow[t]{2}{*}{$\mathrm{OBS}_{t}^{k}$} & + & 0.000108 & $-0.00382^{\star * *}$ \\
\hline & & $(0.000104)$ & $(0.00138)$ \\
\hline \multirow[t]{2}{*}{ Constant } & & $-0.00569^{\star * *}$ & $-0.00558^{\star * *}$ \\
\hline & & $(0.000757)$ & $(0.000745)$ \\
\hline State Dummies & & Yes & Yes \\
\hline Year Dummies & & Yes & Yes \\
\hline $\mathrm{N}$ & & 969 & 918 \\
\hline $\mathrm{R}^{2}$ & & 0.262 & 0.263 \\
\hline
\end{tabular}

This table presents the results of the regression:

$\Delta \ln \mathrm{GSP}_{t}^{k}-\Delta \ln \mathrm{SPI}_{t}^{k}=\alpha+\beta_{0} \Delta \ln \mathrm{GSP}_{t}^{k}+\beta_{1} \mathrm{OBS}_{t}^{k} \times \Delta \ln \mathrm{GSP}_{t}^{k}+\beta_{2} \mathrm{OBS}_{t}^{k}+\delta^{k}+\tau_{t}+\varepsilon_{t}^{k} \quad$, where $\Delta \ln \mathrm{SPI}_{t}^{k}$ denotes the state-specific growth rates of personal income for state $\mathrm{k}$ in year $\mathrm{t}$ and $\ln \mathrm{GSP}_{t}^{k}$ is the state-specific growth rates of gross state product for state $k$ in year $t . \quad \Delta \ln \mathrm{SPI}_{t}^{k}$ and $\ln \mathrm{GSP}_{t}^{k}$ are measured in per capita terms. The growth rates of real per capita variables are calculated as the first differences of the natural log of per capita-level values deflated to $1970 . \mathrm{OBS}_{t}^{k}$ measures the degree of financial innovation of state $k$ in year $t$ and is defined as: 1) the ratio of the aggregate outstanding off-balance-sheet items to the total assets of all banks in a state as reported in Column (1);2) the growth rate of aggregate outstanding off-balance-sheet items of all banks in that state, as reported in Column (2). The OBS data are collected from Schedule RC-L of Call Report in December in each year from the Federal Reserve Bank of Chicago. See Appendix for the details in constructing a consistent time series of this variable. $\delta^{k}$ and $\tau_{t}$ are dummy variables measuring state and time fixed effects respectively. Standard errors are reported in parenthesis. ${ }^{*}$ significant at $10 \% ;{ }^{* *}$ significant at $5 \% ;{ }^{* * *}$ significant at $1 \%$. 
The results in Table 3 clearly suggest that financial innovations significantly contribute to income insurance. As discussed in Section 3.1, we are particularly interested in the interaction term between financial innovation and output growth. In the context of income insurance, we expect a positive sign for the regression coefficient. In Column (1), the average income insurance alone, as measured by $\beta_{0}$, is about $39 \%$ without additional influence. This estimate is both economically and statistically significant. The regression coefficient for the interaction term, $\beta_{1}(=7 \%)$ is statistically and significantly positive. The results in the table show that financial innovation increases the degree of income insurance to $46 \%(39 \%+7 \%)$, a significant improvement in aggregation income risk sharing associated with the development of financial innovation. Similarly, we observe a positive impact of the growth in financial innovation on income insurance, as shown in Column (2).

\section{Conclusions}

There has been an ongoing debate regarding the role of financial innovation in the economy. On the one hand, studies have suggested a negative effect of financial innovation on the economy due to less monitoring on borrowers. This agency problem could potentially lead to poorer performance of the borrower, a higher level of foreclosure rate, which ultimately has an adverse impact on bank stability. On the other hand, proponents of financial innovations argue that financial innovation is a natural response of banks to both sudden shocks and gradual changes in the economy, and that such a Schumpeterian process of innovation is expected to have a positive effect on the economy.

In this study, we examine the impact of financial innovation on the real economy from personal wealth perspectives. Using data on US banks' off-balance sheet from 1995 to 2013 as a proxy of financial innovation used in the banking industry, we investigate aggregate risk sharing in two different channels: personal consumption smoothening and personal income insurance. The results show that in general, the use of financial innovation contributes to a reduction in the exposure of personal income and consumption to state-specific economic shocks. Our findings on the positive role of financial innovation to aggregate risk sharing hence provide complementary evidence to the ongoing debate on the positive role played by financial innovations in the economy.

\section{Conflicts of Interest}

The authors declare no conflicts of interest regarding the publication of this paper.

\section{References}

[1] Marsili, O. and Salter, A. (2005) "Inequality" of Innovation: Skewed Distributions and the Returns to Innovation in Dutch Manufacturing. Economics of Innovation and New Technology, 14, 83-102. https://doi.org/10.1080/1043859042000228642 
[2] Ebersberger, B., Marsili, O., Reichstein, T. and Salter, A. (2008) Fortune Favours the Brave: The Distribution of Innovative Returns in Finland, the Netherlands and the UK. Structural Change and Economic Dynamics, 19, 357-62. https://doi.org/10.1016/j.strueco.2008.01.001

[3] Frame, S.W. and White, L.J. (2004) Empirical Studies of Financial Innovation: Lots of Talk, Little Action. Journal of Economic Literature, 42, 116-144. https://doi.org/10.1257/.42.1.116

[4] Frame, S.W. and White, L.J. (2009) Technological Change, Financial Innovation, and Diffusion in Banking. Federal Reserve Bank of Atlanta Working Paper 2009-10. March.

[5] Grinblatt, M. and Longstaff, F.A. (2000) Financial Innovation and the Role of Derivative Securities: An Empirical Analysis of the Treasury STRIPS Program. Journal of Finance, 55, 1415-1436. https://doi.org/10.1111/0022-1082.00252

[6] Akhavein, J., Frame, S.W. and White, L.J. (2005) The Diffusion of Financial Innovations: An Examination of the Adoption of Small Business Credit Scoring by Large Banking Organizations. The Journal of Business, 78, 577-596. https://doi.org/10.1086/427639

[7] De Young, R. (2005. The Performance of Internet-Based Business Models: Evidence from the Banking Industry. Journal of Business, 78, 893-947.

[8] De Young, R., Lang, W.W. and Nolle, D.L. (2007) How the Internet Affects Output and Performance at Community Banks? Journal of Banking and Finance, 31, 1033-1060.

[9] Gorton, G.B. and Souleles, N. (2006) Special Purpose Vehicles and Securitization. In: Carey, M. and Stulz, R., Eds., The Risks of Financial Institutions, University of Chicago Press, Chicago.

[10] Minton, B.A., Sanders, A. and Strahan, P. (2004) Securitization by Banks and Finance Companies: Efficient Financial Contracting or Regulatory Arbitrage? Working Paper, Ohio State University.

[11] Loutskina, E. (2011) The Role of Securitization in Bank Liquidity and Funding Management. Journal of Financial Economics, 100, 663-684. https://doi.org/10.1016/j.jfineco.2011.02.005

[12] Loutskina, E. and Strahan, P. (2009) Securitization and the Declining Impact of Bank Finance on Loan Supply: Evidence from Mortgage Originations. Journal of Finance, 64, 861-889. https://doi.org/10.1111/j.1540-6261.2009.01451.x

[13] Mian, A. and Sufi, A. (2009) The Consequences of Mortgage Credit Expansion: Evidence from the U.S. Mortgage Default Crisis. The Quarterly Journal of Economics, 124, 1449-1496. https://doi.org/10.1162/qjec.2009.124.4.1449

[14] Demyanyk, Y. and Hemert, V.O. (2011) Understanding the Subprime Mortgage Crisis. Review of Financial Studies, 24, 1848-1880. https://doi.org/10.1093/rfs/hhp033

[15] King, R.G. and Levine, R. (1993) Finance, Entrepreneurship, and Growth: Theory and Evidence. Journal of Monetary Economics, 32, 513-542. https://doi.org/10.1016/0304-3932(93)90028-E

[16] King, R.G. and Levine, R. (1993) Finance and Growth: Schumpeter Might Be Right. The Quarterly Journal of Economics, 108, 717-737. https://doi.org/10.2307/2118406

[17] Beck, T., Levine, R. and Loayza, N. (2000) Financial Intermediation and Growth: Causality and Causes. Journal of Monetary Economics, 46, 31-77.

https://doi.org/10.1016/S0304-3932(00)00017-9 
[18] Beck, T., Chen, T., Lin, C. and Song, F.M. (2016) Financial Innovation: The Bright and the Dark Sides. Journal of Banking and Finance, 72, 26-51. https://doi.org/10.1016/j.jbankfin.2016.06.012

[19] Asdrubali, P., Sorensen, B. and Yosha, O. (1996) Channels of Aggregate Risk Sharing: Unites States 1963-1990. Quarterly Journal of Economics, 111, 1081-1110. https://doi.org/10.2307/2946708

[20] Ashcraft, A.B. and Til, S. (2008) Understanding the Securitization of Subprime Mortgage Credit. Foundations and Trends in Finance, 2, 191-309. https://doi.org/10.1561/0500000024

[21] Piskorski, T., Seru, A. and Vig, V. (2010) Securitization and Distressed Loan Renegotiation: Evidence from the Subprime Mortgage Crisis. Journal of Financial Economics, 97, 369-397. https://doi.org/10.1016/j.jfineco.2010.04.003

[22] Berger, A.N. (2003) The Economic Effects of Technological Progress: Evidence from the Banking Industry. Journal of Money, Credit and Banking, 35, 141-176. https://doi.org/10.1353/mcb.2003.0009

[23] Merton, R.C. (1992) Financial Innovation and Economic Performance. Journal of Applied Corporate Finance, 4, 12-22. https://doi.org/10.1111/j.1745-6622.1992.tb00214.x

[24] Houston, J., Chen, L., Ping, L. and Yue, M. (2010) Creditorrights, Information Sharing and Bank Risk Taking. Journal of Financial Economics, 96, 485-512. https://doi.org/10.1016/j.jfineco.2010.02.008

[25] Liu, P. and Shao, Y. (2013) Small Business Loan Securitization and Interstate Risk Sharing. Small Business Economics, 41, 449-460. https://doi.org/10.1007/s11187-012-9433-0

[26] McCarthy, J. (1997) Debt, Delinquencies, and Consumer Spending. Current Issues in Economics and Finance, 3, 1-6.

[27] Bacchetta, P. and Gerlach, S. (1997) Consumption and Credit Constraints: International Evidence. Journal of Monetary Economics, 40, 207-238. https://doi.org/10.1016/S0304-3932(97)00042-1

[28] Demyanyk, Y., Ostergaard, C. and Sorensen, B. (2007) U.S. Banking Deregulation, Small Business, and Aggregate Insurance of Personal Income. Journal of Finance, 62, 2763-2801. https://doi.org/10.1111/j.1540-6261.2007.01292.x 
Appendix: Schedule RC-L Items in Constructing Time Series of Off-Balance-Sheet Activities

Items in Schedule RC-L of Call Report in December of each year in constructing a consistent time series of off-balance-sheet activities. Call Report data are obtained from the Federal Reserve Bank of Chicago.

\begin{tabular}{|c|c|c|c|c|c|}
\hline 6: & & & & & \\
\hline RCFD3814 & RCFD3815 & RCFD3816 & RCFD6550 & RCFD3817 & RCFD3818 \\
\hline CFD3819 & RCFD3821 & RCFD3411 & RCFD3429 & RCFD3432 & RCFD3650 \\
\hline CFD3652 & RCFD3654 & RCFDA249 & RCFD3434 & RCFD3435 & RCFD8765 \\
\hline RCFD3430 & RCFD5591 & RCFDA126 & RCFDA127 & RCFD8723 & RCFD8724 \\
\hline RCFD8725 & RCFD8726 & RCFD8727 & RCFD8728 & RCFD8729 & RCFD8730 \\
\hline CFD8731 & RCFD8732 & & & & \\
\hline 97-2000: & & & & & \\
\hline RCFD3814 & RCFD3815 & RCFD3816 & RCFD6550 & RCFD3817 & RCFD3818 \\
\hline RCFD3819 & RCFD3821 & RCFD3411 & RCFD3429 & RCFD3432 & RCFDA521 \\
\hline RCFDA523 & RCFDA249 & RCFDA534 & RCFDA535 & RCFD8765 & RCFD3430 \\
\hline RCFD5591 & RCFDA126 & RCFDA127 & RCFD8723 & RCFD8724 & RCFD8725 \\
\hline RCFD8726 & RCFD8727 & RCFD8728 & RCFD8729 & RCFD8730 & RCFD8731 \\
\hline RCFD8732 & & & & & \\
\hline $01-2002:$ & & & & & \\
\hline RCFD3814 & RCFD3815 & RCFD3816 & RCFD6550 & RCFD3817 & RCFD3818 \\
\hline RCFD3819 & RCFD3821 & RCFD3411 & RCFDA534 & RCFDA535 & RCFD8765 \\
\hline RCFD3430 & RCFD5591 & RCFDA126 & RCFDA127 & RCFD8723 & RCFD8724 \\
\hline RCFD8725 & RCFD8726 & RCFD8727 & RCFD8728 & & \\
\hline 003-2005: & & & & & \\
\hline RCFD3814 & RCFD3815 & RCFD3816 & RCFD6550 & RCFD3817 & RCFD3818 \\
\hline RCFD3819 & RCFD3821 & RCFD3411 & RCFDA534 & RCFDA535 & RCFD 8765 \\
\hline RCFD3430 & RCFD5591 & RCFDC223 & RCFDC224 & RCFDA 126 & RCFDA 127 \\
\hline RCFD 8723 & RCFD 8724 & RCFD8725 & RCFD8726 & RCFD 8727 & RCFD 8728 \\
\hline 006-2007: & & & & & \\
\hline RCFD3814 & RCFD3815 & RCFD3816 & RCFD6550 & RCFD3817 & RCFD3818 \\
\hline RCFD3819 & RCFD3821 & RCFD3411 & RCFDC968 & RCFDC969 & RCFDC 970 \\
\hline RCFDC 971 & RCFDC 972 & RCFDC973 & RCFDC 974 & RCFDC975 & RCFD 8765 \\
\hline RCFD3430 & RCFD5591 & RCFDC223 & RCFDC224 & RCFDA 126 & RCFDA 127 \\
\hline RCFD 8723 & RCFD 8724 & RCFD8725 & RCFD8726 & RCFD8727 & RCFD 8728 \\
\hline 008: & & & & & \\
\hline RCFD3814 & RCFD3815 & RCFDF164 & RCFDF165 & RCFD6550 & RCFD3817 \\
\hline RCFD3818 & RCFD3819 & RCFD3821 & RCFD3411 & RCFDC968 & RCFDC969 \\
\hline RCFDC970 & RCFDC971 & RCFDC972 & RCFDC973 & RCFDC974 & RCFDC975 \\
\hline RCFD8765 & RCFD3430 & RCFD5591 & RCFDC223 & RCFDC224 & RCFDA126 \\
\hline RCFDA127 & RCFD8723 & RCFD8724 & RCFD8725 & RCFD8726 & RCFD8727 \\
\hline CFD8728 & & & & & \\
\hline 0 & & & & & \\
\hline
\end{tabular}


RCFD3814 RCFD3815 RCFDF164 RCFDF165 RCFD6550 RCFD3817

RCFD3818 RCFD3819 RCFD3821 RCFD3411 RCFDC968 RCFDC969

RCFDC970 RCFDC971 RCFDC972 RCFDC973 RCFDC974 RCFDC975

RCFD8765 RCFD3430 RCFD5591 RCFDC223 RCFDC224 RCFDA126

RCFDA127 RCFD8723 RCFD8724 RCFD8725 RCFD8726 RCFD8727

RCFD8728 RCFDG418 RCFDG419 RCFDG420 RCFDG421 RCFDG422

2010-2013:

RCFD3814 RCFD3815 RCFDF164 RCFDF165 RCFD6550 RCFD3817 RCFDJ457

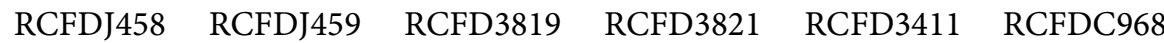

RCFDC969 RCFDC970 RCFDC971 RCFDC972 RCFDC973 RCFDC974

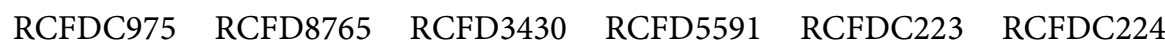

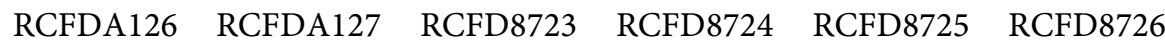

RCFD8727 RCFD8728 RCFDG418 RCFDG419 RCFDG420 RCFDG421

RCFDG422 